\title{
The Effects of Chitosan Oligosaccharide (COS) Treatment on Oxidative Stress and Its Relation with Intestinal Microflora in Rats Exposed To Cadmium
}

\author{
İhsan KISADERE ${ }^{1 *}$, Hakan TAVŞANLI², Mukadderat GÖKMEN³ \\ ${ }^{1 B a l i k e s i r}$ University, Faculty of Veterinary Medicine, Department of Physiology, 10100, Ballkesir, Turkey \\ ${ }^{2}$ Ballkesir University, Faculty of Veterinary Medicine, Department of Public Health, 10100, Balkeesir, Turkey \\ ${ }^{3}$ Balikesir University, Faculty of Veterinary Medicine, Department of Food Hygiene and Technology, 10100, Balkesir, Turkey
}

\begin{abstract}
The aim of the study was to investigate the effects of chitosan oligosaccharide (COS) treatment on oxidative stress and its relation with intestinal microflora in rats exposed to chronic cadmium toxicity. Animals were randomly divided into four groups as control $(C ; n=8)$, cadmium $(C d ; n=8)$, chitosan oligosaccharide (COS; $n=8)$, cadmium+chitosan oligosaccharide $(\mathrm{Cd}+\mathrm{COS} ; \mathrm{n}=8)$. After, cadmium chloride $\left(\mathrm{CdCl}_{2}\right)(2 \mathrm{mg} / \mathrm{kg} /$ day $)$ was orally administered to $\mathrm{Cd}$ and $\mathrm{Cd}+\mathrm{COS}$ groups three times a week for 4 weeks. Chitosan oligosaccharide (200 $\mathrm{mg} / \mathrm{kg} /$ day) was also orally administered to COS and Cd+COS groups five times a week for 4 weeks. After completion of the experiment, serum TAS, TOS levels, plasma ALT, AST, GGT, T.pro, Alb, Bil, Creat and BUN values were measured. Enterobacteriaceae, Lactococcus spp. and Lactobacillus spp. counts were also detected. Serum TOS values were detected extremely higher in Cd group animals when compared COS group $(p<0,05)$. In the small intestine of the Cd group animals, $\mathrm{Cd}$ administration caused a 0.66 log decrease in the Lactococcus spp. count. In conclusion, it was found that the antimicrobial effect of both compounds decreased as a result of COS-Cd chelating in $\mathrm{Cd}+\mathrm{COS}$ group.
\end{abstract}

Keywords: Cadmium, chitosan oligosaccarides, microflora, oxidative stress, rat

\section{Kitosan Oligosakkarit (COS) Tedavisinin Oksidatif Stres Üzerine Etkileri ve Kadmiyuma Maruz Kalan Sıçanlarda Bağırsak Mikroflorası ile İlişkisi}

ÖZ

Bu çalışmanın amacı, kronik olarak Cd'a maruz kalan ratlarda kitosan oligosakkarit'in (COS) oksidatif stress ve bağırsak mikroflorası üzerine etkilerinin araştırlmasıdır. Hayvanlar rastgele olacak şekilde; kontrol $(C ; n=8)$, kadmiyum $(\mathrm{Cd} ; \mathrm{n}=8)$, kitosan oligosakkarit $(\mathrm{COS} ; \mathrm{n}=8)$ ve kadmiyum+kitosan oligosakkarit $(\mathrm{Cd}+\mathrm{COS} ; \mathrm{n}=8)$ gruplarına ayrildi. Daha sonra, kadmiyum klorid $\left(\mathrm{CdCl}_{2}\right)(2 \mathrm{mg} / \mathrm{kg} /$ day $) \mathrm{Cd}$ ve $\mathrm{Cd}+\mathrm{COS}$ gruplarındaki hayvanlara haftada 3 kez 4 hafta boyunca oral yoldan verildi. Kitosan oligosakkarit de $(200 \mathrm{mg} / \mathrm{kg} /$ day) COS ve Cd+COS grubundaki hayvanlara haftada $5 \mathrm{kez} 4$ hafta boyunca oral olarak uyguland. Deneme sonunda, serum TAS, TOS seviyeleri, plasma ALT, AST, GGT, T.pro, Alb, Bil, Creat ve BUN değerleri ölçüldü. Enterobacteriaceae, Lactococcus spp. ve Lactobacillus spp. sayllarıda belirlendi. Serum TOS seviyeleri Cd grubundaki hayvanlarda COS grubundakilere oranla önemli derecede yüksek bulundu ( $\mathrm{p}<0,05)$. Cd grubundaki hayvanların ince bağırsaklarında, kronik Cd uygulaması Lactococcus spp. sayısında 0.66 log'lık bir düşüşe sebep oldu. Sonuç olarak, her iki bileşiğin antimikrobiyel etkinliği şelat oluşumuna bağlı olarak (COS-Cd) $\mathrm{Cd}+\mathrm{COS}$ grubundaki hayvanlarda azalma gösterdi.

Anahtar Kelimeler: Kadmiyum, Kitosan oligosakkarit, mikroflora, oksidatif stres, rat

To cite this article: Kısadere I. Tavşanlı H. Gökmen M. The Effects of Chitosan Oligosaccharide (COS) Treatment on Oxidative Stress and Its Relation with Intestinal Microflora in Rats Exposed To Cadmium. Kocatepe Vet J. (2020) 13(2):110-117 


\section{INTRODUCTION}

Cadmium (Cd), is a non-essential transition metal and considered to be an environmental pollutant, is naturally occurring element that has a high density and atomic weight when compared to water (Tchounwou et al. 2012, Gao et al. 2014). It is released into the environment by various human activities including mining, smelting, and manufacturing of batteries, pigments, stabilizers, and alloys (WHO 2010, Bernhoft 2013, WHO 2019). Cadmium is accumulating in catchments and soils under certain environmental conditions, thus increasing the risk of future exposure through food. The main routes of exposure to $\mathrm{Cd}$ are via ingestion of contaminated foods such as vegetables, potatoes, rice, wheat, green leafy grains and seeds, liver and kidney, and crustaceans and mollusks as well as contaminated water (IARC 1993, Paschal et al. 2000, Satarug et al. 2003, WHO 2007, ATSR 2008) It has been reported that acute or chronic exposed to $\mathrm{Cd}$ induces lipid peroxidation (LPO) (by stimulation of occuring superoxide anions) and oxidative stress (by increasing free radical production) in the cells (ElDemerdash et al. 2004, López et al. 2006). Morever, it initiates various adverse effects in human and animals such as kidney dysfunction, liver injury and osteoporosis (Tchounwou et al. 2012, Satarug et al. 2011, Amamou et al. 2015). Cd accumulation is mainly occured in the kidney and liver but also in brain, lung, bones, pancreas, placenta and testis in the body (Satarug et al. 2011, Amamou et al. 2015, Fowler 2009). In addition, $\mathrm{Cd}$ is a severe gastrointestinal irritant, which can leads to abdominal pain, burning sensation, nausea, vomiting, salivation when acute high dose ingested (Baselt and Cravey 1995, Hammett-Stabler 2000).

The gastrointestinal tract, is the interface between ingested nutrients and the body, plays an important role in maintaining of the health, food intake and regulating energy homeostasis (Zhang et al. 2014, Monteiro et al. 2017). In GIS, there are many bacterial populations whose have mutual relationship with intestinal epithelial cells that are known as symbiosis. Although Enterobacteriaceae are normal flora of the human intestinal system, they are common opportunistic pathogens can translocate across the mucosal barrier and lead to systemic infections if intestinal counts are extremely increased (Hsueh et al. 2010, Toh et al.2012, Lai et al. 2016, Jean et al. 2016). On the other hand, lactic acid bacteria such as Lactococcus spp. and Lactobacillus spp also inhabit in the GIS that can produce lactic acid, acetic acid, formic acid and other acids to reduce intestinal $\mathrm{pH}$. Besides, these microorganisms can secrete some antimicrobial molecules, such as ethanol, fatty acid, hydrogen peroxide and bacteriocins to defense against pathogenic bacteria in GIS (Ralitsa et al. 2015, Inglin et al. 2015). Although above mentioned bacteria populations are mainly affected by the host's diet intake, the prevalence of bacteria in different parts of the GI tract appears to be depending on certain factors, such as $\mathrm{pH}$, peristalsis, redox potential, bacterial adhesion, bacterial cooperation, mucin secretion, nutrient availability and bacterial antagonism (Tannock 1983, Roberfroid et al. 2010, Amato et al. 2013). Imbalance among the intestinal epithelial cells, pathogen and/or commensal bacteries increases the rate of intestinal microbial disorders and sensitivity to external harmful compounds (Costello et al.2012, Salim et al. 2014, Woodmansey 2007). Heavy metals also reach GI tract through ingestion of contaminated food and water. Although the toxicological effect of heavy metals on different body structures were detected, especially $\mathrm{Cd}$, on GI microflora, is still remains unclear (Upreti et al. 2004, Inaba et al. 2005, Monachese et al. 2012).

Recently, it has been reported that harmfull effects of $\mathrm{Cd}$ can be ameliorated by using some chelating agents, antioxidants, probiotics and vitamins (Pourmorad et al.2006, fang 2007, El-boshy et al. 2014, Djurasevic et al. 2017). One of them is chitosan oligosaccharide (COS) that is produced by chitosan/chitin via chemical hydrolysis or enzymatic degradation, known for its ability to bind to divalent cations such as $\mathrm{Cd}$. As it known, it has an antioxidant, free radical consumer, antimicrobial, antifungal, antiinflammatory, anti-diabetic and anti-obesity properties (Guan et al. 2016, Kim et al. 2016, Naveed et al. 2019). Therefore, our study has been designed to evaluate the influences of oral COS administration on oxidative stress, and its relation with intestinal microflora of the rats exposed to chronic $\mathrm{Cd}$ toxicity.

\section{MATERIALS and METHODS}

\section{Animals, Study Design and Experimental Procedure}

Male albino Wistar rats $(n=32$; body weight $\sim 200 \pm$ $30 \mathrm{~g}$ ) were housed in standard plastic rat cages at $23 \pm$ $2{ }^{\circ} \mathrm{C}$ room temperature, $55 \pm 10 \%$ relative humidity and 12 hours night/day light period during the experiment. The animals had free access to drinking water and standart rat feed. All experimental procedures were approved by the Ethical Committee on Animal Experimentation of the University of Balikesir (2019/4-6). Before the experiment, animals were randomly divided into four groups as control (C; $\mathrm{n}=8)$, cadmium $(\mathrm{Cd} ; \mathrm{n}=8)$, chitosan oligosaccharide (COS; $\mathrm{n}=8)$, cadmium+chitosan oligosaccharide $(\mathrm{Cd}+\mathrm{COS} ; \mathrm{n}=8)$. Then, animals in $\mathrm{C}$ group received standard rat feed and fresh drinking water ad libitum. Cadmium chloride $\left(\mathrm{CdCl}_{2}\right)$ (2mg / day) were orally administered to $\mathrm{Cd}$ and $\mathrm{Cd}+\mathrm{COS}$ groups three times a week for 4 weeks. On the other hand, chitosan oligosaccharide $(200 \mathrm{mg} / \mathrm{kg} /$ day $)$ was also orally administered to COS and $\mathrm{Cd}+\mathrm{COS}$ groups five times a week for 4 weeks. After completion of the 
experiment (4 weeks later), rats were anesthetized by intraperitoneal injection of ketamine/xylazine $(0.1$ $\mathrm{ml} / 100 \mathrm{gm} /$ body weight) and killed by cervical dislocation technique. Blood samples were collected via cardiac puncture and transferred into tubes. Plasma and serum were obtained from the blood samples by using a centrifuge $(3000 \mathrm{rpm}, 25 \mathrm{~min}$, Heichrich, Germany). Obtained samples were stored at minus $80{ }^{\circ} \mathrm{C}$ in a refrigeratior until analysis time. Besides, intestinal fluid content were aseptically collected from the small and large intestines of the each rats.

\section{Determination of total antioxidant and oxidants levels}

Serum total antioxidant status (TAS) and oxidant status (TOS) values were defined by ELISA (Thermoscientific Elisa Reader, USA) using commercial kits (Rel Assay Diagnostics, Gaziantep, Turkey), according to Erel's method that is automated and colorimetric (Erel 2004, Erel 2005).

\section{Determination of some plasma enzyme levels}

Plasma alanine amino transferase (ALT), aspartate amino transferase (AST), gamma glutamyl transferase (GGT), total protein (T.pro), albumine (Alb), bilirubin (Bil), creatinine (Creat) and blood urea nitrogen (BUN) values were measured by using automatic biochemical analyser (Architect C-8000, Abbott, USA) with commercial kits according to manufacturer instructions.

\section{Microbiological analysis}

During the necropsy, $1 \mathrm{~g}$ intestinal fluid content were aseptically collected from the small and large intestines of the each rats (separately with 3 replicates). Then, they were homogenized in the stomacher for 2 minutes with sterile $9 \mathrm{ml}$ Maximum Recovery Diluent (MRD), serial dilutions were prepared from $10^{-1}$ to $10^{-6}$. For determine to the Enterobacteriaceae count, $1 \mathrm{ml}$ of the dilution was taken and cultured in Violet Red Glucose Bile (VRGB, Oxoid CM1082) Agar according to the double-plate technique. The plates were evaluated as Enterobacteriaceae because of the observing purple-pink colonies after aerobic incubation at $37^{\circ} \mathrm{C}$ for $24 \mathrm{~h}$ (ISO 21528-2: 2017). On the other hand, $0.1 \mathrm{ml}$ of the dilution was taken and cultured in the M17 (Oxoid CM0785) agar according to spread plate technique for despite to Lactococcus spp count. Then, plates were evaluated as Lactococcus spp depends on occuring yellow-cream colonies after anaerobic incubation at $30^{\circ} \mathrm{C}$ for $24 \mathrm{~h}$ (Lee et al.2010). For detection of Lactobacillus spp count, $0.1 \mathrm{ml}$ of dilution was cultured on MRS (CM0361) agar. Plates were also evaluated as Lactobacillus spp. due to occuring of yellow-cream colonies after anaerobic incubation at $37^{\circ} \mathrm{C}$ for $72 \mathrm{~h}$ (Bauer et al. 2002).

\section{Statistical Analysis}

Obtained datas were analyzed with using SPSS for Windows version 25.0, and levels were presented as means \pm SE. Differences among the groups were performed by analysis of variance (one-wayANOVA) that is followed by Duncan's test.

\section{RESULTS and DISCUSSION}

Serum TOS values were detected extremely higher in $\mathrm{Cd}$ group animals when compared COS group ( $\mathrm{p}$ $<0,05)$. On the other hand, it was not found significant difference among $\mathrm{C}, \mathrm{Cd}$ and $\mathrm{Cd}+\mathrm{COS}$ groups according to TOS values, shown in Table 1 . In addition, serum TAS values decreased due to $\mathrm{Cd}$ administration in $\mathrm{Cd}$ group animals compared to other groups $(\mathrm{p}<0,05)$.

Plasma Bil and Creat levels were found the highest in $\mathrm{Cd}$ group compared to other groups $(\mathrm{p}<0,05)$. Besides, COS administration did not lead to any changes in $\mathrm{Cd}+\mathrm{COS}$ group according to Bil and Creat levels $(p>0,05)$. Conversely, plasma T.pro and $\mathrm{Alb}$ values were detected lower in $\mathrm{Cd}$ group compared to $\mathrm{C}, \mathrm{COS}$ and $\mathrm{Cd}+\mathrm{COS}(\mathrm{p}<0,05)$. In addition, plasma BUN levels were ameliorated due to COS administration in $\mathrm{Cd}+\mathrm{COS}$ group $(\mathrm{p}<0,05)$. Although plasma ALT, AST and GGT levels were detected higher in $\mathrm{Cd}$ group, the levels of the mentioned parameters decreased in COS group animals, statistically $(\mathrm{p}<0,05)$, shown in Table 2 .

The average Enterobacteriaceae, Lactococcus spp. and Lactobacillus spp. counts were detected as 4.34, 4.25 $\log \mathrm{cfu} / \mathrm{g}, 6.47 ; 7.09 \log \mathrm{cfu} / \mathrm{g} ; 8.37,7.39 \log \mathrm{cfu} /$ $\mathrm{g}$ in both (small and large) intestines of the control group animals, respectively. On the other hand, Enterobacteriaceae counts were found similar in the control group with another experimental groups in both small and large intestines $(\mathrm{P}>0.05)$. In the small intestine of the $\mathrm{Cd}$ group animals, $\mathrm{Cd}$ administration caused a $0.66 \mathrm{log}$ decrease in the Lactococcus spp. count. In contrary, $\mathrm{Cd}+\mathrm{COS}$ chelate lead to increase in the counts of Lactococcus spp. in small intestines of the rats $(p<0.01)$. There was a significant difference between the $C$ group and the other experimental groups according to Lactobacillus spp. count in small intestines $(\mathrm{p}<0.01)$. Besides, Lactobacillus spp. counts significantly decreased in $\mathrm{Cd}$, COS and $\mathrm{Cd}+\mathrm{COS}$ when compared to the $\mathrm{C}$ group. In terms of Lactobacillus spp, the highest decrease was observed in the small intestines of the COS group animals. In the large intestines of the rats, Lactobacillus spp. count significantly increased in COS and $\mathrm{Cd}+\mathrm{COS}$, however decreased in $\mathrm{Cd}$ group when compared to $C(p<0.01)$. The highest increase in the Lactobacillus spp. counts were observed as $0.54 \mathrm{log}$ in the $\mathrm{Cd}+\mathrm{COS}$ group, shown in Table 3. 
Although $\mathrm{Cd}$ is a well-known environmental pollutant which induces severe organ and tissue damage in human and animals, effect of Cd on GI microflora and its relation with oxidative stress is still remains unclear (Satarug et al. 2011, Amamou et al. 2015, Fowler 2009).

In present study, exposed to chronic $\mathrm{Cd}$ toxicity increased (not statistically) the serum TOS levels, however significantly supressed the serum TAS in Cd group animals. These results were consistent with previous studies (Karabulut-Bulan et al. 2008, Koçak and Akçil 2006, Kumaş et al. 2016). Either increased TOS nor decreased TAS levels were ameliorated with COS treatment in $\mathrm{Cd}+\mathrm{COS}$ group when compared to $\mathrm{Cd}$ in our study. Similarly, the dose of chitosan more than $20 \mathrm{mg} / \mathrm{kg} /$ day was found effective on Cdinduced oxidative damage (SOD activity and MDA content) in the rat kidney by Zhou et al. (2013). Protective effects of COS and chitin on various metal and chemical compound induced oxidative stress were also determined by other researchers which was consistent with our results (Kim et al. 2005, Yan et al. 2006, Li et al. 2011, Toz and Değer 2018). It can be considered that the administration of COS reinforced the antioxidant defence system and also ameliorated the $\mathrm{Cd}$ induced oxidative stress in present study.

In our study, oral Cd treatment (low dose, $2 \mathrm{mg} / \mathrm{kg}$ ) led to increase of plasma ALT, AST, GGT enzyme levels (an important indicators of liver functions) in Cd group animals. Besides, an important markers of kidney functions are BUN and Creat levels also negative effected by $\mathrm{Cd}$ treatment in present study. These findings were corresponding with previous studies (Koçak and Akçil 2006, Lakshmi et al. 2012, Renugadevi and Milton 2010). Although plasma ALT, AST, GGT and BUN levels were improven by using COS in experimental groups, it couldn't affect to the plasma Creat levels in our study, interestingly. It was also reported that high dose chitosan diet ameliorated the Cd induced increased AST levels but did not lead to significance alterations in plasma ALT, BUN and Creat levels (Kim et al. 2016). In addition, T.pro and Alb values also negative effected by $\mathrm{Cd}$ toxicity in $\mathrm{Cd}$ group animals. It was consistent with Hussein et al. (2009) and Oyinloye et al. (2016). Increased liver and kidney enzyme levels, and reduction of T.pro and Alb values confirm the tissue damege due to chronic $\mathrm{Cd}$ toxicity in present study. There was limited information about the effects of COS on T.pro and Alb levels of $\mathrm{Cd}$ induced toxication in rats. Bil levels also increased in $\mathrm{Cd}$ group animals but did not effected from COS administration in present study. Hamden et al. (2009), Ibiam et al. (2013) and Markiewicz-Górka et al. (2011) also defined similar results in $\mathrm{Cd}$ treated rats according to Bil values. It may be explained that COS can be partially ameliorated the $\mathrm{Cd}$ induced tissue damages in the liver and kidney.
In the small intestinal microflora of the rats, neither Cd nor COS didn't cause any significant changes in the counts of Enterobacteriaceae in present study. Conversely, Escherichia coli and Klebsiella spp., which are the members of Enterobacteriaceae group, counts decreased due to $\mathrm{Cd}$ (high doses) treatments in the small intestine of the mouse in a previous study (Fazeli et al. 2011). As it known, COS has positive effects on host gut health and intestinal microbial community (Zhang et al. 2014), however Cd+COS treatment not affected the Enterobacteriaceae count in our study. It can be explained by either antimicrobial effect of both compounds decreased as a result of COS $+\mathrm{Cd}$ chelating, both compounds were rapidly absorbed without showing their antimicrobial effects or the doses were insufficient to demonstrate known effects. In addition, $\mathrm{Cd}$ treatment did not lead to changes in Enterobacteriaceae count in large intestine in $\mathrm{Cd}$ group compared to $\mathrm{C}$ group. It has been suggested that E. coli and Klebsiella spp. counts reduced in the large intestine of the mice due to $\mathrm{Cd}$ in a previous study which was not corresponding with present study (Fazeli et al. 2011). Although it has been enounced that COS influences GI flora, and thus improving intestinal health, it was not found a significant change in Enterobacteriaceae counts in the large intestine of the $\mathrm{Cd}+\mathrm{COS}$ group animals. It can be occured due to different dose, time of exposure to $\mathrm{Cd}$ and/or animal species.

A significant decrease was found in the count of Lactococcus spp. in small intestine of Cd group animals in present study. It was also suggested that grampositive basilcus and enterecocus microorganisms were more sensitive to $\mathrm{Cd}$ toxicity than gram-negative E. coli and Klebsiella spp. (Fazeli et al. 2011). On the other hand, $\mathrm{Cd}+\mathrm{COS}$ treatment increased the Lactococcus spp count in large intestine of the rats. These results can be explained by the fact that total bacterial rates of microflora varied with decreased count of Enterobacteriaceae due to $\mathrm{Cd}+\mathrm{Mel}$ administration or the high $\mathrm{pH}$ in the small intestine.

Lactobacillus spp. count was found lower in Cd group than $\mathrm{C}, \mathrm{Mel}$ and $\mathrm{Cd}+\mathrm{Mel}$ groups in small intestine microflora of the rats in our study. It has been reported by Fazeli et al. (Fazeli et al. 2011). that Lactobacillus spp. count decreased due to different high doses of $\mathrm{Cd}$ treatment in small intestines of the mice which was corresponding with our results. Although decreased Lactobacillus spp. counts were detected by Fazeli et al. (2011) in large intestines depend on the different doses of $\mathrm{Cd}$, it increased due to $\mathrm{Mel}$ and $\mathrm{Cd}+\mathrm{Mel}$ treatments in large intestine of the rats except $\mathrm{C}$ group in our study. It was also reported that Mel treatment increased the Lactobacillus spp. counts in large intestines of colitic mice which was consistent with present study (Wang et al. 2019). It can be also expressed that $\mathrm{Cd}+\mathrm{Mel}$ treatment may be reduced Enterobacteriaceae count and lead to 
increase Lactobacillus spp./Lactococcus spp. rates, and/or activated the antioxidant system that can be confirmed by an increase in serum TAS levels in our study.

Table 1. Serum TAS and TOS levels in different experimental groups.

\begin{tabular}{lcccc}
\hline \multicolumn{5}{c}{ Groups } \\
\hline Parameters & $\begin{array}{c}\mathbf{C} \\
(\mathbf{n = 8})\end{array}$ & $\begin{array}{c}\text { COS } \\
(\mathbf{n}=\mathbf{8})\end{array}$ & $\begin{array}{c}\mathbf{C d} \\
(\mathbf{n = 8})\end{array}$ & $\begin{array}{c}\mathbf{C d}+\mathbf{C O S} \\
(\mathbf{n = 8})\end{array}$ \\
\hline TOS & $26,50 \pm 5,94^{\mathrm{a}}$ & $2,97 \pm 1,08^{\mathrm{b}}$ & $69,65 \pm 29,95^{\mathrm{a}}$ & $32,45 \pm 11,54^{\mathrm{a}}$ \\
TAS & $1,73 \pm 0,03^{\mathrm{a}}$ & $1,81 \pm 0,00^{\mathrm{a}}$ & $0,73 \pm 0,01^{\mathbf{b}}$ & $1,73 \pm 0,02^{\mathrm{a}}$ \\
\hline
\end{tabular}

a,b,c; The differences between average values indicated by different letters in the same row of the same parameters are important $(p<0.05)$.

Table 2. The average biochemical parameters in different experimental groups $(\mathrm{X} \pm \mathrm{SEM})$.

\begin{tabular}{|c|c|c|c|c|}
\hline \multicolumn{5}{|c|}{ Groups } \\
\hline Parameters & $\underset{(n=8)}{C}$ & $\begin{array}{c}\mathrm{COS} \\
(\mathrm{n}=8)\end{array}$ & $\begin{array}{c}\mathrm{Cd} \\
(\mathrm{n}=8)\end{array}$ & $\begin{array}{c}\mathrm{Cd}+\mathrm{COS} \\
(\mathrm{n}=8)\end{array}$ \\
\hline Bil (g/L) & $1.02 \pm 0.00^{\mathrm{b}}$ & $1.03 \pm 0.02^{b}$ & $1.35 \pm 0.07^{\mathrm{a}}$ & $1.08 \pm 0.01^{b}$ \\
\hline $\operatorname{ALT}(\mathbf{U} / \mathbf{L})$ & $37.82 \pm 1,94^{\mathbf{c}}$ & $37.65 \pm 1.19^{\mathbf{c}}$ & $81.01 \pm 5.18^{\mathrm{a}}$ & $72.80 \pm 4.72^{b}$ \\
\hline $\operatorname{AST}(\mathbf{U} / \mathbf{L})$ & $60.16 \pm 4,03^{\mathrm{c}}$ & $62.16 \pm 5.17^{\mathrm{c}}$ & $147.0 \pm 16.82^{\mathrm{a}}$ & $108.16 \pm 9.88^{b}$ \\
\hline GGT (U/L) & $1.16 \pm 0,11^{\mathrm{c}}$ & $1.15 \pm 0.12^{\mathrm{c}}$ & $2.50 \pm 0.23^{\mathrm{a}}$ & $1.40 \pm 0.24^{\mathrm{b}}$ \\
\hline Alb (g/dL) & $3.51 \pm 0,11^{\mathrm{a}}$ & $3.51 \pm 0.14^{\mathrm{a}}$ & $2.84 \pm 0.21^{\mathbf{b}}$ & $3.53 \pm 0.90^{\mathrm{a}}$ \\
\hline BUN (mg/dl) & $18.70 \pm 1.21^{\mathrm{c}}$ & $16.11 \pm 1.35^{\mathrm{d}}$ & $40.71 \pm 2.25^{\mathrm{a}}$ & $30.26 \pm 2.24^{\mathbf{b}}$ \\
\hline Creat $(\mathrm{mg} / \mathrm{L})$ & $5.04 \pm 1.02^{\mathbf{b}}$ & $5.06 \pm 0.99^{\mathbf{b}}$ & $7.41 \pm 0.88^{\mathrm{a}}$ & $4.99 \pm 1.02^{\mathbf{b}}$ \\
\hline T.Pro (g/dL) & $5.57 \pm 0,13^{\mathrm{a}}$ & $5.20 \pm 0.13^{\mathrm{a}}$ & $4.56 \pm 0.15^{\mathrm{b}}$ & $5.12 \pm 0.19^{\mathrm{a}}$ \\
\hline
\end{tabular}

a,b,c,d; The differences between average values indicated by different letters in the same row of the same parameters are important $(p<0.05)$.

Table 3. Enterobacteriaceae, Lactococcus ssp. and Lactobacillus spp. counts in different experimental groups.

\begin{tabular}{llccc}
\hline Groups & & Enterobacteriaceae & Lactococcus ssp & Lactobacillus spp. \\
\hline Control & small & $4,3438 \pm 0,15^{\mathrm{a}}$ & $6,4771 \pm 0.00^{\mathrm{ab}}$ & $8,3764 \pm 0.80^{\mathrm{abc}}$ \\
& large & $4,2580 \pm 0.00^{\mathrm{a}}$ & $7,0922 \pm 0.58^{\mathrm{ab}}$ & $7,6931 \pm 0.29^{\mathrm{bcd}}$ \\
\hline $\boldsymbol{C O S}$ & small & $4,1664 \pm 0.23^{\mathrm{a}}$ & $6,8368 \pm 0.54^{\mathrm{ab}}$ & $7,1238 \pm 0.75^{\mathrm{a}}$ \\
& large & $4,1838 \pm 0.28^{\mathrm{a}}$ & $7,5131 \pm 0.24^{\mathrm{ab}}$ & $8,6993 \pm 0.97^{\mathrm{ab}}$ \\
\hline $\boldsymbol{C d}$ & small & $4,6819 \pm 0.24^{\mathrm{a}}$ & $5,8458 \pm 0.29^{\mathrm{b}}$ & $8,1228 \pm 0.33^{\mathrm{abcd}}$ \\
& large & $5,3764 \pm 0.2^{\mathrm{a}}$ & $6,3280 \pm 0.67^{\mathrm{ab}}$ & $7,3920 \pm 0.38^{\mathrm{cd}}$ \\
\hline $\boldsymbol{C d}+\boldsymbol{C O S}$ & small & $4,1230 \pm 0.9^{\mathrm{a}}$ & $7,6723 \pm 0.99^{\mathrm{ab}}$ & $7,2177 \pm 0.76^{\mathrm{cd}}$ \\
& large & $4,4269 \pm 0.01^{\mathrm{a}}$ & $8,1476 \pm 0.60^{\mathrm{a}}$ & $8,9155 \pm 0.29^{\mathrm{a}}$
\end{tabular}

a,b,c,d; The differences between average values indicated by different letters in the same line of the same parameters are important $(p<0.05)$.

\section{CONCLUSION}

It is known that lactic acid bacteria and probiotics should be taken with food at a level of at least $7 \log /$ gr in order to have beneficial effects in humans. Taking this information into account, both Lactococcus ssp. and Lactobacillus spp. counts decreased as 0.63 and $0.77 \log$ in the Cd group compared to the control group, respectively. This decrease in lactic acid bacteria may also be related with serum TAS and TOS values in $\mathrm{Cd}$ group animals. In addition, it was found that the antimicrobial effect of both compounds decreased as a result of COS-Cd chelating in $\mathrm{Cd}+\mathrm{COS}$ group. This situation can be 
observed in terms of serum TAS and TOS levels in our study.

\section{ACKNOWLEDGEMENT}

All experimental procedures were approved by the Ethical Committee on Animal Experimentation of the University of Balikesir (2019/4-6).

Conflict of Interest: The authors declare that they have no conflict of interest.

\section{REFERENCES}

Agency for Toxic Substances and Disease Registry (ATSDR). Toxicological Profile for Cadmium ATSDR, Atlanta, Georgia (2008), p. 454.

Amamou F, Nemmiche S, Meziane RK, Didi A, Yazit SM, Chabane-Sari D. Protective effect of olive oil and colocynth oil against cadmiuminduced oxidative stress in the liver of Wistar rats. Food Chem Toxicol.2015;78:17784.DOI: $10.1016 /$ j.fct.2015.01.001.

Amato SM, Orman MA, Brynildsen MP. Metabolic control of persister formation in Escherichia coli. Mol Cell. 2013; 50(4): 475-487. DOİ: 10.1016/j.molcel.2013.04.002.

Baselt, RC, Cravey RH. Disposition of Toxic Drugs and Chemicals in Man. 4th Edn. Chicago,IL: Year Book Medical Publishers; 1995. pp. 105-107.

Bauer TM, Fernández J, Navasa M, Vila J, Rodés J. Failure of Lactobacillus spp. to prevent bacterial translocation in a rat model of experimental cirrhosis. J Hepatol, 2002; 36(4), 501-506. DOI:10.1016/S0168-8278(02)00003-X.

Bernhoft RA. Cadmium toxicity and treatment. Sci.World J.2013:394652. DOİ:10.1155/2013/394652.

Costello EK, Stagaman K, Dethlefsen L, Bohannan BJ, Relman DA. The application of ecological theory toward an understanding of the human microbiome. Science. 2012; 336(6086):1255-1262. DOI: $10.1126 /$ science. 1224203 .

Djurasevic S, Jama A, Jasnic N, Vujovic P, Jovanovic M, Mitic-Culafic D, Knezevic-Vukcevic J, CakicMilosevic M, Ilijevic K, Djordjevic J. The Protective Effects of Probiotic Bacteria on Cadmium Toxicity in Rats. J Med Food. 2017; 20(2):189-196. DOI: 10.1089/jmf.2016.0090.

El-Boshy ME, Risha EF, Abdelhamid FM, Mubarak MS, Hadda TB. Protective effects of selenium against cadmium induced hematological disturbances, immunosuppressive, oxidative stress and hepatorenal damage in rats. J Trace Elem Med Biol. 2014; 29: 104-10. DOİ:10.1016/j.jtemb.2014.05.009.

El-Demerdash FM, Yousef MI, Kedwany FS, Baghdadi HH. Cadmium-induced changes in lipid peroxidation, blood hematology, biochemical parameters and semen quality of male rats: protective role of vitamin $\mathrm{E}$ and betacarotene. Food Chem Toxicol. 2004; 42(10):1563-1571. DOI: $10.1016 /$ j.fct.2004.05.001

Erel O. A new automated colorimetric method for measuring total oxidant status. Clin biochem. 2005; 38(12): 11031111. DOI: $10.1016 /$ j.clinbiochem.2005.08.008

Erel O. A novel automated direct measurement method for total antioxidant capacity using a new generation, more stable
ABTS radical cation. Clin biochem. 2004; 37: 277-285. DOI: 10.1016/j.clinbiochem.2003.11.015.

Fang C. Characterization of Polyphenol Oxidase and Antioxidants From Pawpaw (Asimina Tribola) Fruit. 2007; University of Kentucky Master's Theses 477. https://uknowledge.uky.edu/gradschool_theses/477.

Fazeli M, Hassanzadeh P, Alaei S. Cadmium chloride exhibits a profound toxic effect on bacterial microflora of the mice gastrointestinal tract. Hum Exp Toxicol. 2011; 30(2): 152-159. DOI: 10.1177/096032711036982.

Fowler BA. Monitoring of human populations for early markers of cadmium toxicity: A review. Toxicol Applied Pharma. 2009; 238(3): 294-300. DOI: 10.1016/j.taap.2009.05.004.

Gao D, Xu Z, Kuang X, Qiao P, Liu S, Zhang L, He P, Jadwiga WS, Wang Y, Min W. Molecular characterization and expression analysis of the autophagic gene beclin 1 from the purse red common carp (Cyprinus carpio) exposed to cadmium. Comp Biochem Physiol C Toxicol Pharmacol. 2014; 160:15-22.

Guan G., Wang H., Chen S., Liu G., Xiong X., Tan B., Duraipandiyan V, Al-Dhabi NA, Fang J. Dietary chitosan supplementation increases microbial diversity and attenuates the severity of Citrobacter rodentium infection in mice. Mediat Inflamm. 2016:9236196. DOI:10.1155/2016/9236196.

Hamden K, Allouche N, Damak M, Elfeki A. Hypoglycemic and antioxidant effects of phenolic extracts and purified hydroxytyrosol from olive mill waste in vitro and in rats. Chem Biol Interact. 2009;180(3):421-32. DOI: 10.1016/j.cbi.2009.04.002.

Hammett-Stabler CA. Disposition of Toxic Drugs and Chemicals in Man, 5th ed. R.C. Baselt. Foster City, CA: Chemical Toxicology Institute, 1999, 900 pp., \$119.00. ISBN 0-9626523-3-4. Published June 2000.

Hsueh PR, Badal RE, Hawser SP, Hoban DJ, Bouchillon SK, Ni Y, Paterson DL. Epidemiology and antimicrobial susceptibility profiles of aerobic and facultative gram-negative bacilli isolated from patients with intra-abdominal infections in the Asia-Pacific region: 2008 results from SMART (Study for Monitoring Antimicrobial Resistance Trends). Int $\mathrm{J}$ Antimicrob Agents. 2010:36(5):408-414. DOI: 10.1016/j.ijantimicag.2010.07.002.

Hussein SA, Abd-el-maksoud HA, Agag BI, El-nile MB. Effect of cadmium toxicity on some biochemical blood parameters and their modulation with certain natural antioxidants in rabbits. Benha Ras Surd. 2009; 338-62.

Ibiam AU, Ugwuja EI, Ejeogo C, Ugwu O. CadmiumInduced Toxicity and the Hepatoprotective Potentials of Aqueous Extract of Jessiaea Nervosa Leaf. Adv Pharm Bull. 2013; 3(2), 309-313. DOİ: 10.5681/apb.2013.050

Inaba T1, Kobayashi E, Suwazono Y, Uetani M, Oishi M, Nakagawa $\mathbf{H}$, Nogawa $\mathbf{K}$. Estimation of cumulative cadmium intake causing Itai-itai disease. Toxicol Lett. 2005; 159: 192-201. DOI: 10.1016/j.toxlet.2005.05.011

Inglin RC, Stevens MJ, Meile L, Lacroix C, Meile L. Highthroughput screening assays for antibacterial and antifungal activities of Lactobacillus species. J Microbiol Methods. 2015; 114:26-29. DOI: 10.1016/j.mimet.2015.04.011.

International Agency for Research on Cancer (IARC). Cadmium and cadmium compounds. IARC Monogr Eval Carcinog Risks Hum. 1993; 58: 119-237. 
ISO 21528-2:2017. Microbiology of the food chain - Horizontal method for the detection and enumeration of Enterobacteriaceae — Part 2: Colony-count technique

Jean SS, Coombs G, Ling T, Balaji V, Rodrigues C, Mikamo H, Kim MJ, Rajasekaram DG, Mendoza M, Tan TY1, Kiratisin P1, Ni Y1, Weinman B, Xu Y, Hsueh PR. Epidemiology and antimicrobial susceptibility profiles of pathogens causing urinary tract infections in the Asia-Pacific region: results from the study for monitoring antimicrobial resistance trends (SMART), 2010-2013. Int J Antimicrob. Agents. 2016; 47(4):328-34. DOI: 10.1016/j.ijantimicag.2016.01.008.

Karabulut-Bulan O, Bolkent S, Yanardag R, Bilgin-Sokmen B. The role of vitamin $\mathrm{C}$, vitamin $\mathrm{E}$, and selenium on cadmium-induced renal toxicity of rats. Drug Chem Toxicol. 2008; 31(4): 413-26. DOI: $10.1080 / 01480540802383200$

Kim KN, Joo ES, Kim KI, Kim, SK, Yang HP, Jeon YJ. Effect of chitosan oligosaccharides on cholesterol level and antioxidant enzyme activities in hypercholesterolemic rat. J Korean Soc Food Sci Nutr. 2005; 34(1):36-41. DOİ:10.3746/jkfn.2005.34.1.036.

Kim MY, Shon WJ, Park MN, Lee YS, Shin DM. Protective effect of dietary chitosan on cadmium accumulation in rats. Nutr Res Pract. 2016; 10(1):19-25. DOI:10.4162/nrp.2016.10.1.19

Koçak M, Akçil E. The effects of chronic cadmium toxicity on the hemostatic system. Pathophysiol Haemost Thromb. 2006; 35(6): 411-416. DOI: 10.1159/000102047

Kumas M, Esrefoglu M, Bayindir N, Iraz M, Ayhan S, Meydan S. Protective Effects of Curcumin on Cadmium-Induced Renal Injury in Young and Aged Rats. Bezmialem Science. 2016; 3: 92-8. DOI: $10.14235 /$ bs. 2016.788

Lai CC, Chen CC, Huang HL, Chuang YC, Tang HJ. The role of doxycycline in the therapy of multidrug-resistant E. coli - an in vitro study. Sci. Rep. 2016; 6:31964. DOI: $10.1038 / \operatorname{srep} 31964$

Lakshmi GD, Kumar PR, Bharavi K, Annapurna P, Rajendar B, Patel PT, Kumar CS, Rao GS. Protective effect of Tribulus terrestris linn on liver and kidney in cadmium intoxicated rats. Indian J Exp Biol. 2012; 50(2): $141-146$.

Lee, K. C., Liu, C. F., Lin, T. H., and Pan, T. M. Safety and risk assessment of the genetically modified Lactococci on rats intestinal bacterial flora. Int J Food Microbiol. 2010; 142, 164-169. DOI: 10.1002/iub.1027

Li R, Zhou Y, Ji J, Wang L. Oxidative damages by cadmium and the protective effects of low-molecular-weight chitosan in the freshwater crab (Sinopotamon yangtsekiense Bott 1967). Aquac Res. 2011; 42(4):506515. DOİ: $10.1111 / j .1365-2109.2010 .02646 . x$.

López E, Arce C, Oset-Gasque MJ, Cañadas S, González MP. Cadmium induces reactive oxygen species generation and lipid peroxidation in cortical neurons in culture. Free Radical Biol Med.2006;40(6):940-951. DOI: 10.1016/j.freeradbiomed.2005.10.062

Markiewicz-Górka I1, Zawadzki M, Januszewska L, Hombek-Urban K, Pawlas K. Influence of selenium and/or magnesium on alleviation alcohol induced oxidative stress in rats, normalization function of liver and changes in serum lipid parameters. Hum Exp Toxicol. 2011; 30(11): 1811-1827. DOI: 10.1177/0960327111401049.

Monachese M, Burton JP, Reid G. Bioremediation and tolerance of humans to heavy metals through microbial processes: a potential role for probiotics? Appl Environ Microbiol. 2012; 78 (18): 6397-6404. DOI: 10.1128/AEM.01665-12.

Monteiro MP, Batterham RL. The Importance of the Gastrointestinal Tract in Controlling Food Intake and Regulating Energy Balance. Gastroenterology. 2017; 52(7):1707-1717. DOİ: 10.1053/i.gastro.2017.01.053

Naveed M, Phil L, Sohail M, Hasnat M, Baig MMFA, Ihsan AU, Shumzaid M, Kakar MU, Khan TM, Akabar MD, Hussainc MI, Zhou QG. Chitosan oligosaccharide (COS): An overview. Int $\mathrm{J}$ Biol Macromol. 2019; 129:827-843. DOI: 10.1016/j.ijbiomac.2019.01.192

Oyinloye BE, Ajiboye BO, Ojo OA, Musa HM, Onikanni SA, Ojo AA. Ameliorative potential of Aframomum melegueta extract in cadmium- induced hepatic damage and oxidative stress in male Wistar rats. J Appl Pharm Sci. 2016; 6(7):94-99. DOİ: 10.7324/JAPS.2016.60714.

Pourmorad F, Hosseinimehr SJ, Shahabimajd N. Antioxidant activity, phenol and flavonoid contents of some selected Iranian medicinal plants. Afr J Biotechnol. 2006; 5 (11): 1142-45. doi:10.1055/s-2007-987042.

Ralitsa G, Lyubomira Y, Lilia T, Galina Z, Nina S, Akseniya A, Antonia D, Gergana I, Nikolay K, Nevenka R, Elena K. Antimicrobial activity and antibiotic susceptibility of Lactobacillus and Bifidobacterium spp. intended for use as starter and probiotic cultures. Biotechnol Biotechnol Equip. 2015; 29(1): 84-91. DOİ:10.1080/13102818.2014.987450.

Renugadevi J, Milton prabu S. Quercetin protects against oxidative stress-related renal dysfunction by cadmium in rats. Exp Toxicol Pathol. 2010; 62(5): 471-81. DOİ:10.1016/j. etp.2009.06.006.

Roberfroid M, Gibson GR, Hoyles L. et al., "Prebiotic effects: metabolic and health benefits," Br J Nutr. 2010; 104 (2): pp. S1-S63.

Salim SY, Jovel J, Wine E, Kaplan GG, Vincent R, Thiesen A, Barkema HW, Madsen KL. Exposure to ingested airborne pollutant particulate matter increases mucosal exposure to bacteria and induces early onset of inflammation in neonatal IL-10-deficient mice. Inflamm Bowel Dis. 2014;20(7):1129-38. DOI: 10.1097/MIB.0000000000000066

Satarug S, Baker JR, Urbenjapol S, Haswell-Elkins M, Reilly PE, Williams DJ, Moore MR. A global perspective on cadmium pollution and toxicity in non-occupationally exposed population. Toxicol Lett. 2003;137 (1-2):65-83. DOİ:10.1016/S0378-4274(02)00381-8.

Satarug S, Garrett SH, Sens MA, Sens DA. Cadmium, environmental exposure, and health outcomes. Cien Saude Colet. 2011;16(5): 2587-2602. DOI: 10.1289/ehp.0901234.

Tannock IF. Methotrexate and mitomycin for patients with metastatic transitional cell carcinoma of the urinary tract. Cancer Treat Rep. 1983; 67 (5): 503-504.

Tchounwou PB, Yedjou CG, Patlolla AK, Sutton DJ. Heavy Metals Toxicity and the Environment. EXS. 2012; 101:133-164. DOİ:10.1007/978-3-7643-8340-4_6.

Toh HS1, Chuang YC, Huang CC, Lee YL, Liu YM, Ho CM, Lu PL, Liu CE, Chen YH, Wang JH, Ko WC, Yu KW, Liu YC, Chen YS, Tang HJ, Hsueh PR. Antimicrobial susceptibility profiles of gram-negative bacilli isolated from patients with hepatobiliary infections in Taiwan: results from the study for monitoring antimicrobial resistance trends (SMART), 2006-2010. Int 
J Antimicrob Agents. 2012; 40S1: S18-S23. DOI: 10.1016/S0924-8579(12)70005-5.

Toz H, Değer Y. The Effect of Chitosan on the Erythrocyte Antioxidant Potential of Lead Toxicity-Induced Rats. Biol Trace Elem Res. 2018; 184(1):114-118. DOI: 10.1007/s12011-017-1164-2

Upreti RK, Shrivastava R, Chaturvedi UC. Gut microflora \& toxic metals: chromium as a model. Indian J Med Res. 2004; 119: 49-59.

Wang J, Zhang C, Guo C, Li X. Chitosan Ameliorates DSSInduced Ulcerative Colitis Mice by Enhancing Intestinal Barrier Function and Improving Microflora. Int. J. Mol. Sci. 2019; 20(22): E5751. DOI: 10.3390/ijms20225751.

Woodmansey EJ. Intestinal bacteria and ageing. J Appl Microbiol. 2007; 102: 1178-1186. DOİ:10.1111/j.13652672.2007.03400.x

World Health Organization (WHO). Health risks of heavy metals from long-range transboundary air pollution. Copenhagen, World Health Organization Regional Office for $\quad$ Europe, 2007; (http://www.euro.who.int/document/E91044.pdf)

World Health Organization (WHO). Exposure to Cadmium: A Major Public Health Concern. 2019; 1-6: https://www.who.int/ipcs/assessment/public_health/ca dmium/en/

Yan Y, Wanshun L, Baoqin $H$, Bing L, Chenwei $F$. Protective effects of chitosan oligosaccharide and its derivatives against carbon tetrachloride-induced liver damage in mice. Hepatol Res. 2006; 35:178-184. DOI: 10.1016/j.hepres.2006.04.001.

Zhang P, Liu W, Peng Y, Han B, Yang Y. Toll like receptor 4 (TLR4) mediates the stimulating activities of chitosan oligosaccharide on macrophages. Int Immunopharmacol. 2014; 23(1): 254-261. DOI: 10.1016/j.intimp.2014.09.007.

Zhou Y, Gao B, Zimmerman AR, Fang J, Sun Y, Cao X. Sorption of heavy metals on chitosan-modified biochars and its biological effects. Chem Eng J. 2013; 231:512518. DOI: 10.1016/j.cej.2013.07.036.

Zohouri A, Tekeli SK. Ratlarda Kadmiyumun Metabolizma Üzerindeki Etkilerinin Araştırılması. Istanbul Üniv Vet Fak Derg. 1999; 25(2): 261-71. 